Effect of a Dynamic Climate on Energy Consumption and Production of Hibiscus rosa-sinensis L. in Greenhouses

\author{
Janni Bjerregaard Lund ${ }^{1}$ and Andrea Andreassen \\ The Royal Veterinary and Agricultural University, Section of Crop Science, \\ DK-2630 Taastrup, Denmark
}

\section{Carl-Otto Ottosen}

Danish Institute of Agricultural Sciences, Department of Horticulture, DK5792 Aarslev, Denmark

\section{Jesper Mazanti Aaslyng}

The Royal Veterinary and Agricultural University, Section of Crop Science, DK-2630 Taastrup, Denmark

Additional index words. photosynthesis, light integral, relative humidity, production timing, dynamic climate control, models and stem elongation

\begin{abstract}
Production in a dynamic photosynthesis optimized climate (DC) was compared to production in a traditional and more stable climate (TC). Production of a tropical plant species (Hibiscus rosa-sinensis L.) in a DC resulted in between $18 \%$ and $63 \%$ reduction in energy use, mainly due to lower temperatures and increased use of thermal screens. In high light periods, the average day temperatures (ADT) were virtually the same in the different treatments, while in low light periods both ADT and average night temperature (ANT) were lower in the DC. Differential use of the screens resulted in a higher cumulative light integral in the DC. The number of lateral breaks was either the same or higher in the DC. Dry weight at the end of the production period was not significantly different in six of the seven experiments, and in five out of seven replications, plants grown in the DC were shorter than plants in the TC. Production periods between 10 days shorter and 21 days longer, for the DC compared to the TC, could not be explained by temperature integration alone. In the DC, a high positive DIF (difference between ADT and ANT) does not seem to increase elongation growth. The study illustrates that it is possible to produce a heat-demanding plant and save energy using a DC.
\end{abstract}

One of the most energy-demanding industries in Denmark is the production of potted plants (Skov et al., 1993). Most energy is consumed on heating and artificial lighting, and attempts to lower energy consumption have included the use of thermal screens (Bailey, 1988), new cover material (Bredenbeck, 1989) and alternative energy sources (Bredenbeck, 1989; Santamouris et al., 1994). Another option, however, is a changed climate strategy. A more dynamic climate (DC) strategy than traditionally used (TC) can reduce energy use (Bailey and Seginer, 1989; Cockshull, 1994; Hansen et al., 1996ab; Ottosen et al., 2004).

It has proved possible to produce high quality plants with less static temperature control (Bailey and Seginer, 1989; Ottosen et al., 2004), and models for dynamic $\mathrm{CO}_{2}$ optimization have evolved based on the financial benefits of enrichment and on the costs of $\mathrm{CO}_{2}$. Although less $\mathrm{CO}_{2}$ is used, a greater yield of, for example, sweet pepper and cucumber can be produced (Ehler and Karlsen, 1993; Nederhoff, 1988). Another important aspect of a DC strategy is

Received for publication 4 Oct. 2005. Accepted for publication 6 Dec. 2005.

${ }^{1}$ To whom reprint requests should be addressed; e-mailjblu@kvl.dk. production in this DC was higher, while energy consumption decreased. The lower energy consumption was mainly due to a minimum temperature of $15^{\circ} \mathrm{C}$. Because of the promising results obtained, greenhouse conditions by Aaslyng et al. (1999) were hereafter used. At the same time, improvements were made to save natural heating by applying models for ventilation and screening. The technical aspects of the system are described in Aaslyng et al. (2003). In experiments with roses, energy savings in the DC were $8 \%$ compared to the TC when plants were grown from April to June, and $40 \%$ in plants grown from March to May (Aaslyng et al., 1999). Since the minimum temperature is $15^{\circ} \mathrm{C}$ and many potted plants produced in greenhouses have a tropical origin, the aim of this study was to see the effect of the photosynthesis optimized and energy saving climate on growth and production time when producing Hibiscus rosa-sinensis L., a tropical, temperature-demanding plant.

\section{Materials and Methods}

The mathematical models, rules and strategies used in the system combine the biological processes, costs and physical factors influencing production (see Table 1 for an overview of the strategies used). Climate strategies were determined in real-time with intervals of $10 \mathrm{~min}$.

The system optimizes the photosynthesis in several steps.

1) Irradiance is measured at canopy level.

2) An array of photosynthesis rates is calculated as a function of temperature and $\mathrm{CO}_{2}$ concentration. The rates are calculated using a leaf photosynthesis model with fixed stomata resistance. As existing photosynthesis models cannot explain all details of the canopy photosynthesis on the many different pot plants grown in greenhouses, this system does not attempt to model the real canopy photosynthesis, but instead a more accurately defined model for leaf layer (Aaslyng et al., 2003).

3) The maximum net assimilation rate is determined from the array of photosynthetic rates.

4) The lowest temperature and $\mathrm{CO}_{2}$ concentration are determined in relation to the photosynthesis setpoints. In these and earlier experiments, $80 \%$ of maximal photosynthesis was used, as this has been proven to give good quality plants with less energy consumption compared to $100 \%$ (maximal photosynthesis). However, using $100 \%$ photosynthesis as the setpoint results in shorter production periods. Since it is technically possible to use waste $\mathrm{CO}_{2}$ from the burning of fossil fuel for heating the greenhouse, $\mathrm{CO}_{2}$ was considered to be less harmful to the environment than the energyuse needed to obtain a high temperature. The system, therefore, searches through all $\mathrm{CO}_{2}$ concentrations at a given temperature before proceeding to the next, higher temperature to find setpoints for temperature and $\mathrm{CO}_{2}$.

5) The calculated $\mathrm{CO}_{2}$ concentration was decreased by $10 \%$, in order to adapt the often high $\mathrm{CO}_{2}$ requirements estimated by the leaf photosynthesis model to a level that is economi- 
cally feasible for commercial growing. This is an empirically selected decrease of the $\mathrm{CO}_{2}$ that is used only for economic purposes.

The system also incorporates models for securing optimal use of natural energy. The operation of vents was therefore delayed significantly compared to standard procedures, the temperature being allowed to rise to 30 ${ }^{\circ} \mathrm{C}$ before opening the vents. At temperatures $>33^{\circ} \mathrm{C}$, the screens were used for shading until the greenhouse had cooled to $25^{\circ} \mathrm{C}$. During the night, the temperature dropped passively to the night temperature setpoint. The use of screens in the daytime was limited as much as possible to obtain maximum PPF. The economically optimum time for withdrawal of thermal screens at dawn was determined using a thermal screen simulation system. The energy saved, resulting from keeping the screens closed, is balanced against the production loss caused by the decrease in irradiance, as a result of the shading effect of the screens. The system uses a fixed price for energy all year round, while the economical production loss depends on the month of the year. The system has been described in detail in Aaslyng et al. (2003).

A TC was used for comparison, with the setpoints indicated in Table 1. Supplementary lighting was the same in both treatments. In each compartment, supplementary lighting of $55 \mathrm{~W} \cdot \mathrm{m}^{-2}$ installed capacity (SON-T, $400 \mathrm{~W}$; Philips, The Netherlands) was used for $17 \mathrm{~h}$ (6:00 to 23:00 HR). Artificial light level at plant height was $150 \mu \mathrm{mol} \cdot \mathrm{m}^{-2} \cdot \mathrm{s}^{-1}$.

In both $\mathrm{DC}$ and $\mathrm{TC}$, the climate data were logged every minute, and new setpoints were generated and downloaded to the standard environmental control computer (LCC1200, Senmatic, Denmark) every $10 \mathrm{~min}$. Data were collected at three levels: 1) at the weather station outside the greenhouses $(1 \mathrm{~m}$ above the greenhouse), 2) in the greenhouses just above the plant canopy, and 3) in the top of the plant canopy. Air speed $\left(0.2\right.$ to $75 \pm \approx 0.1 \mathrm{~m} \cdot \mathrm{s}^{-1}$ below $\left.10 \mathrm{~m} \cdot \mathrm{s}^{-1}\right)(\mathrm{A} 100$, Vector Instruments, $\mathrm{UK})$, air temperature $\left(-50\right.$ to $100 \pm 0.2{ }^{\circ} \mathrm{C}$ ) (10K3MCD1, BetaTHERM, Ireland) and total irradiance (305 to $2800 \mathrm{~nm} \pm \approx 1.5 \%$ ) (CM11 Pyranometer, Kipp and Zonen, Holland) were measured at the outside weather station. Air temperature (10K3MCD1; BetaTHERM, Ireland), $\mathrm{CO}_{2}$ concentration ( 0 to $2000 \mathrm{ppm}$, $\pm 10 \mathrm{ppm}$ ) (URAS 4; Hartmann and Brun, Germany), air humidity ( $0 \%$ to $100 \%, \pm 1.5 \%$ ) (HygroClip S, Rotronic, Switzerland), total irradiance (CM-11 Pyranometer; Kipp and Zonen, Holland) and PPF (400 to $700 \mathrm{~nm} \pm$ $\approx 2.5 \%$ )(LI-190SA; Li-Cor, Lincoln, Neb., and G1126-02; Hamamatsu Photonics, Japan) were measured at the greenhouse level.

$\mathrm{PPF}$ air temperature and $\mathrm{CO}$, were measured at the plant canopy level with the same sensors as at the greenhouse level. Measurements of the infrared leaf surface temperature $\left(-45\right.$ to $\left.290^{\circ} \mathrm{C}\right)$ (IRt/c.01; Exergen) were used in the control of the screens and the leaf tissue temperature was measured with thermocouples, type $\mathrm{Cu} / \mathrm{Con}$ (Sensycon, Hartmann and Braun, Germany). An average of four PPF measurements at canopy level was used as input value for the photosynthesis model. The DC was designed as an add-on to a standard environmental control computer and was integrated through the 'BipsArch' application interface developed for the research by Aaslyng et al. (2005).

Calculations of ANT were based on temperature measurements when PPF was near zero, while ADT was based on temperature measurements in the photoperiod. AT was the 24-h temperature average. DIF was calculated by subtracting ANT from ADT. The average temperature integration $\left(\mathrm{TI},{ }^{\circ} \mathrm{C} \cdot \mathrm{d}^{-1}\right)$ was calculated and multiplied by the number of days in the production period to obtain the cumulative temperature integration $\left(\mathrm{CTI},{ }^{\circ} \mathrm{C}\right)$. A similar calculation was done with the cumulative light integral $\left(\mathrm{CLI}, \mathrm{mol} \cdot \mathrm{m}^{-2}\right)$. All calculations were done using the climate measurements that were logged every minute.

Experimentalset-up. The experiments were carried out during the period 1998-2002 in Copenhagen (lat. $55^{\circ} \mathrm{N}$, long. $12^{\circ} \mathrm{E}$ ). Rooted and pinched cuttings of Hibiscus rosa-sinensis L. 'Cairo' were delivered from a commercial nursery in $12-\mathrm{cm}$ pots, with four plants in each pot. The high number of plants per pot was chosen to mimic the grower's production. The four greenhouse compartments (Danish freestanding greenhouse) used for the experiments were $66 \mathrm{~m}^{2}$ each, and the two treatments were alternated between all greenhouse compartments. The experimental periods differed in length because of differences in production time (plants with one open flower were regarded as sellable). There were 40 plants $/ \mathrm{m}^{2}$ in each treatment and a $7-\mathrm{m}^{2}$ table was covered with plants.

Table 1. Overview of climate strategies and setpoints in the dynamic (DC) and traditional (TC) climate. General strategies are indicated on the left side and limits and setpoints for the actual crop are shown in the right columns

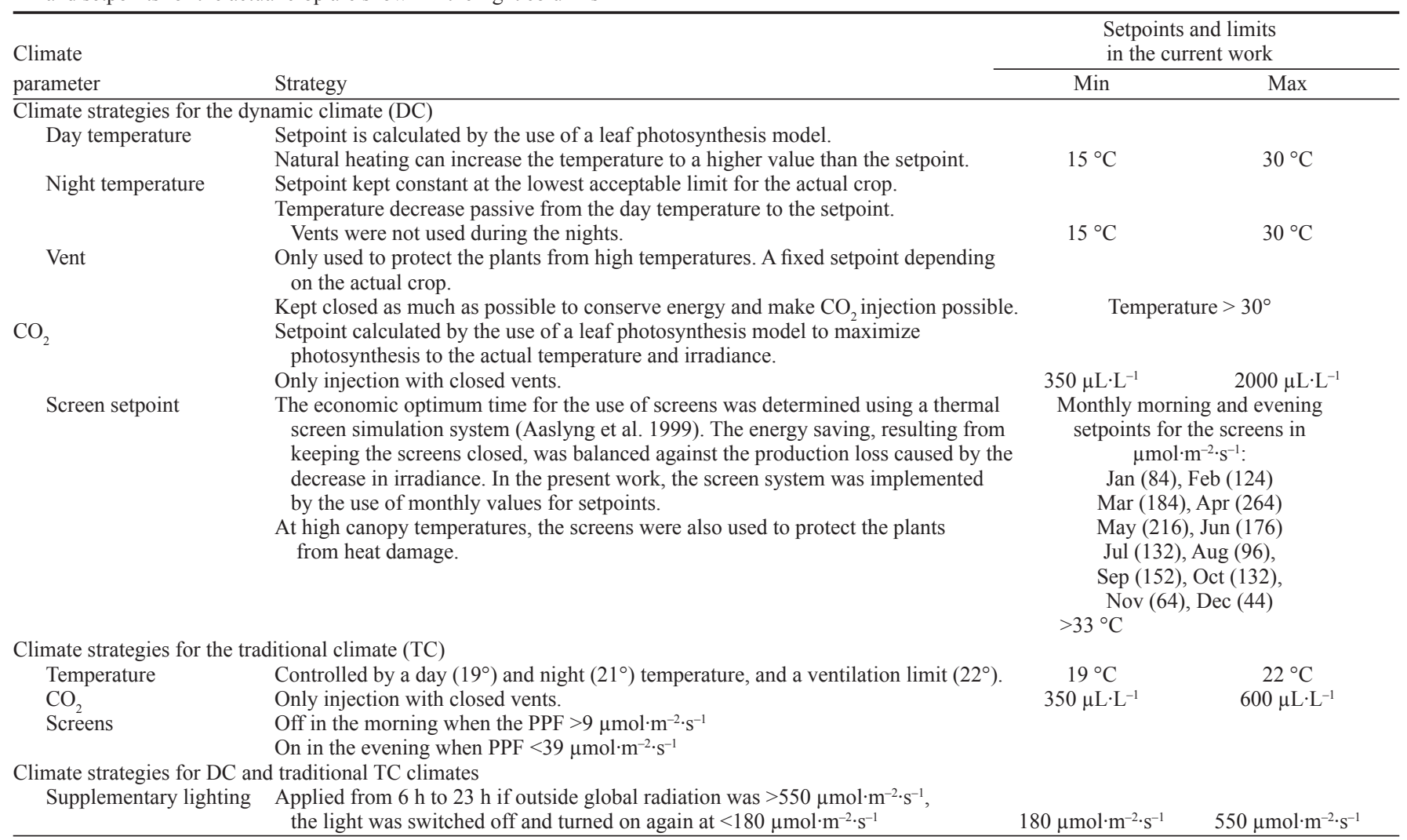


Heating, ventilation vents, thermal screens, $\mathrm{CO}_{2}$ supply and fertilization in the greenhouses were all computer-controlled. Ebb-flood irrigation was carried out manually, as uniformly as possible, in an attempt to produce the identical substrate wetness, irrespective of treatment.

Plant height was measured from the soil surface to the highest point of the tallest plant. Numbers of buds $(>1 \mathrm{~cm})$, flowers (when the petals started to unfold, aborted flowers included) and lateral breaks (with one visible leaf) were counted. To measure dry weight, plants were cut at the soil surface and dried at $86^{\circ} \mathrm{C}$ for $48 \mathrm{~h}$ (Termaks; TS 8280, Norway). An initial measurement was made with eight plants. In the following 3 weeks, eight plants were harvested from each treatment. When plants had one fully opened flower, the date was noted and the production period was calculated as the number of treatment days (initial age of plants was not included). After harvesting, the plants were moved to maintain the same plant density throughout the entire experiment.

Energy calculations. Water flow $(0.5 \%$ of measured value) (Ecoflux IFM 1010K; Krohne, Germany) and temperature ( -50 to $100 \pm 0.2$ $\left.{ }^{\circ} \mathrm{C}\right)(10 \mathrm{~K} 3 \mathrm{MCD} 1$; BetaTHERM) of the water in in-going and out-going heating pipes were measured to calculate the energy required for heating. For artificial lighting, energy was calculated based on registering when the lamps were on, the number of lamps and the energy used from the lamps and ballast. Calculation of the total energy consumption $\left(P_{\text {tot }}, \mathrm{W}\right)$ was based on the equation: $P_{\text {tot }}=\rho\left(T_{\mathrm{i}}^{\text {tot }}-T_{\mathrm{o}}\right) f+$ $i_{\mathrm{s}} P_{\mathrm{i}}$, where $\rho$ was the specific heat of water $\left({ }^{\mathrm{J}} \cdot{ }^{\circ} \mathrm{C}^{-1} \cdot \mathrm{kg}^{-1}\right), T$ the inlet temperature $\left({ }^{\circ} \mathrm{C}\right)$ of the heating water, $T_{\mathrm{o}}$ the outlet temperature $\left({ }^{\circ} \mathrm{C}\right), f$ the flow of water $\left(\mathrm{kg} \cdot \mathrm{s}^{-1}\right), i$ the current status of the supplementary irradiance (on/off) and $P_{\mathrm{i}}$ the installed lamp and ballast effect (W).

Statistical design and analysis. The experiment was designed in two treatments (blocks), repeated seven times in the period 1998-2002.
Experimental data on plant growth were analyzed statistically using least significant difference (LSD). The analyses were carried out using SAS statistical software (SAS Institute, 1985).

\section{Results and Discussion}

The results indicate that it is possible to save between $40 \%$ and $64 \%$ total energy consumption during the spring months (experiments starting in February and April) and between $19 \%$ and $46 \%$ during the winter months (experiments starting in November and January) (Table 2). The lower temperatures (Table 3) were the main reason for the lower energy consumption in the DC, but use of the thermal screens was also an important factor limiting energy consumption.

The experiments can be divided into high light periods $\left(\mathrm{PPF}>300 \mu \mathrm{mol} \cdot \mathrm{m}^{-2} \cdot \mathrm{s}^{-1}\right)$ and low light periods (PPF $<300 \mu \mathrm{mol} \cdot \mathrm{m}^{-2} \cdot \mathrm{s}^{-1}$ ), depending on the light level in the DC (Table 3). In high light periods, the ADT was almost the same in the two treatments. ANT was still lower in the DC compared to the TC. During low light periods, both ADT and ANT were lower in the DC. The screen model pulled the screens on for a longer period during morning and evening in the DC compared to the TC. The screens were never used in the DC to shade, in contrast to the TC where they were used at an irradiance level $>1380 \mu \mathrm{mol} \cdot \mathrm{m}^{-2} \cdot \mathrm{s}^{-1}$. The difference in screen use was apparent in a higher CLI in the DC compared to the TC. There were between 10 (summer) and 46\% (early spring) more light in the DC. The low temperatures allowed in the DC could have been critical, as they cause an increase in relative humidity $(\mathrm{RH})$. Condensation was found on the inside of the greenhouse construction but not on the plants, and so Botrytis infection was not a problem. The average $\mathrm{CO}_{2}$ concentrations in the two treatments were almost equal, but during a day in the $\mathrm{DC}$ the $\mathrm{CO}_{2}$ concentration fluctuated according to the actual irradiance, while in TC it was controlled all the time resulting in a more constant concentration throughout the photoperiod.

Production time. Production periods in the DC are between $10 \mathrm{~d}$ shorter and $21 \mathrm{~d}$ longer than in the TC. An extended production period would be unacceptable in the commercial production of potted plants, and so the photosynthesis optimization level could have been increased to shorten the production period. However, there is no difference in production time during high light periods. In three of the seven experiments, production time in DC and TC differed by only one day (Table 3 ). The TI is often regarded as being related to production period (Cockshull et al., 1981; Körner and Challa, 2004; Rijsdijk, 2000). This correlation was also found in our study, but it does not explain all the results. Plants in the TC utilized the TI more efficiently than plants in the DC (Fig. 1). A large bandwidth of $\pm 8^{\circ} \mathrm{C}$ for temperature setpoint (corresponding to DC) in chrysanthemum, resulted in a longer production time compared to a narrow bandwidth of $\pm 4^{\circ} \mathrm{C}$, although temperature integrals differed slightly (Körner and Challa, 2004). The connection between TI, temperature bandwidth and production time in the DC is fairly complex. The CTI was lower in the DC than in the TC (Fig. 1). Based on the correlation between production time and CTI (Fig. 1) and to results in chrysanthemum with different temperature bandwidths (Körner and Challa, 2004), a longer production period might have been expected in all experiments, but this was not found. More research is needed to explain the connection between climates, carbon gain and production time in the DC. Conclusions from research in the more traditional climates cannot explain the plant responses to the fullest degree.

Plant analysis. In the production of potted plants, temperature and radiation are important

Table 2. Effects of dynamic (DC) and traditional (TC) climates on energy consumption ( $\left.\mathrm{MJ} \mathrm{m}^{-2}\right)$ in the seven replications. Energy saving (\%) is total energy saving when comparing DC to TC.

\begin{tabular}{|c|c|c|c|c|c|c|c|}
\hline \multirow{2}{*}{$\begin{array}{l}\text { Experimental } \\
\text { period }\end{array}$} & \multicolumn{2}{|c|}{$\begin{array}{l}\text { Energy for heating } \\
\left(\mathrm{MJ} \cdot \mathrm{m}^{-2}\right)\end{array}$} & \multicolumn{2}{|c|}{$\begin{array}{l}\text { Energy for } \\
\text { artificial lighting } \\
\left(\mathrm{MJ} \cdot \mathrm{m}^{-2}\right)\end{array}$} & \multicolumn{2}{|c|}{$\begin{array}{c}\text { Total energy } \\
\text { consumption } \\
\left(\mathrm{MJ} \cdot \mathrm{m}^{-2}\right)\end{array}$} & \multirow[t]{2}{*}{$\begin{array}{c}\text { Energy saving } \\
(\%)\end{array}$} \\
\hline & $\mathrm{DC}$ & $\mathrm{TC}$ & $\mathrm{DC}$ & $\mathrm{TC}$ & $\mathrm{DC}$ & $\mathrm{TC}$ & \\
\hline January 1998-April 1998 & 103.0 & 274.2 & 231.8 & 162.1 & 334.8 & 436.4 & 23.3 \\
\hline November 1998-February 1999 & 121.2 & 563.6 & 592.4 & 513.6 & 713.6 & 1077.3 & 33.8 \\
\hline February 1999-May 1999 & 53.0 & 475.8 & 469.7 & 495.5 & 522.7 & 971.2 & 46.2 \\
\hline January 2000-April 2000 & 222.7 & 530.3 & 227.3 & 307.6 & 450.0 & 837.9 & 46.3 \\
\hline April 2000-June 2000 & 18.2 & 72.7 & 47.0 & 106.1 & 65.2 & 178.8 & 63.6 \\
\hline January 2002-April 2002 & 333.3 & 490.9 & 309.1 & 298.5 & 642.4 & 789.4 & 18.6 \\
\hline April 2002-June 2002 & 16.7 & 147 & 175.8 & 172.7 & 192.4 & 319.7 & 39.8 \\
\hline
\end{tabular}

Table 3. Measured climate and production period. Average day temperature (ADT), average night temperature (ANT), average 24-h temperature (AT), average photosynthetic photon flux (PPF) and average daytime $\mathrm{CO}_{2}$ concentration.

\begin{tabular}{|c|c|c|c|c|c|c|c|c|c|c|c|c|}
\hline \multirow{2}{*}{$\begin{array}{l}\text { Experimental } \\
\text { period }\end{array}$} & \multicolumn{2}{|c|}{$\begin{array}{l}\text { Production period } \\
\text { (d) }\end{array}$} & \multicolumn{2}{|c|}{$\begin{array}{l}\text { ANT } \\
\left({ }^{\circ} \mathrm{C}\right)\end{array}$} & \multicolumn{2}{|c|}{$\begin{array}{l}\mathrm{ADT} \\
\left({ }^{\circ} \mathrm{C}\right)\end{array}$} & \multicolumn{2}{|c|}{$\begin{array}{l}\mathrm{AT} \\
\left({ }^{\circ} \mathrm{C}\right)\end{array}$} & \multicolumn{2}{|c|}{$\begin{array}{c}\mathrm{PPF} \\
\left(\mu \mathrm{mol} \cdot \mathrm{m}^{-2} \cdot \mathrm{s}^{-1}\right)\end{array}$} & \multicolumn{2}{|c|}{$\begin{array}{c}\mathrm{CO}_{2} \\
\left(\mu \mathrm{L} \cdot \mathrm{L}^{-1}\right)\end{array}$} \\
\hline & $\mathrm{DC}$ & $\mathrm{TC}$ & $\mathrm{DC}$ & $\mathrm{TC}$ & $\overline{\mathrm{DC}}$ & $\mathrm{TC}$ & $\overline{\mathrm{DC}}$ & $\mathrm{TC}$ & $\mathrm{DC}$ & $\mathrm{TC}$ & $\overline{\mathrm{DC}}$ & $\mathrm{TC}$ \\
\hline January 1998-April 1998 & 76 & 77 & 21.3 & 21.7 & 16.9 & 20.6 & 19.9 & 21.4 & 352 & 268 & 561 & 507 \\
\hline November 1998-February 1999 & 93 & 84 & 18.5 & 21.0 & 15.5 & 19.4 & 17.7 & 20.5 & 205 & 159 & 548 & 546 \\
\hline February 1999-May 1999 & 106 & 116 & 22.2 & 23.5 & 16.7 & 20.0 & 20.4 & 22.3 & 249 & 175 & 718 & 627 \\
\hline January 2000-April 2000 & 114 & 93 & 19.7 & 21.0 & 16.0 & 20.9 & 18.2 & 21.0 & 269 & 178 & 504 & 582 \\
\hline April 2000-June 2000 & 67 & 68 & 25.3 & 23.8 & 18.7 & 21.0 & 22.7 & 23.0 & 363 & 321 & 388 & 389 \\
\hline January 2002-April 2002 & 103 & 98 & 20.3 & 21.9 & 15.9 & 19.2 & 18.6 & 21.1 & 126 & 118 & 576 & 582 \\
\hline April 2002-June 2002 & 64 & 63 & 23.7 & 24.2 & 17.9 & 20.3 & 21.9 & 23.1 & 173 & 132 & 609 & 449 \\
\hline
\end{tabular}




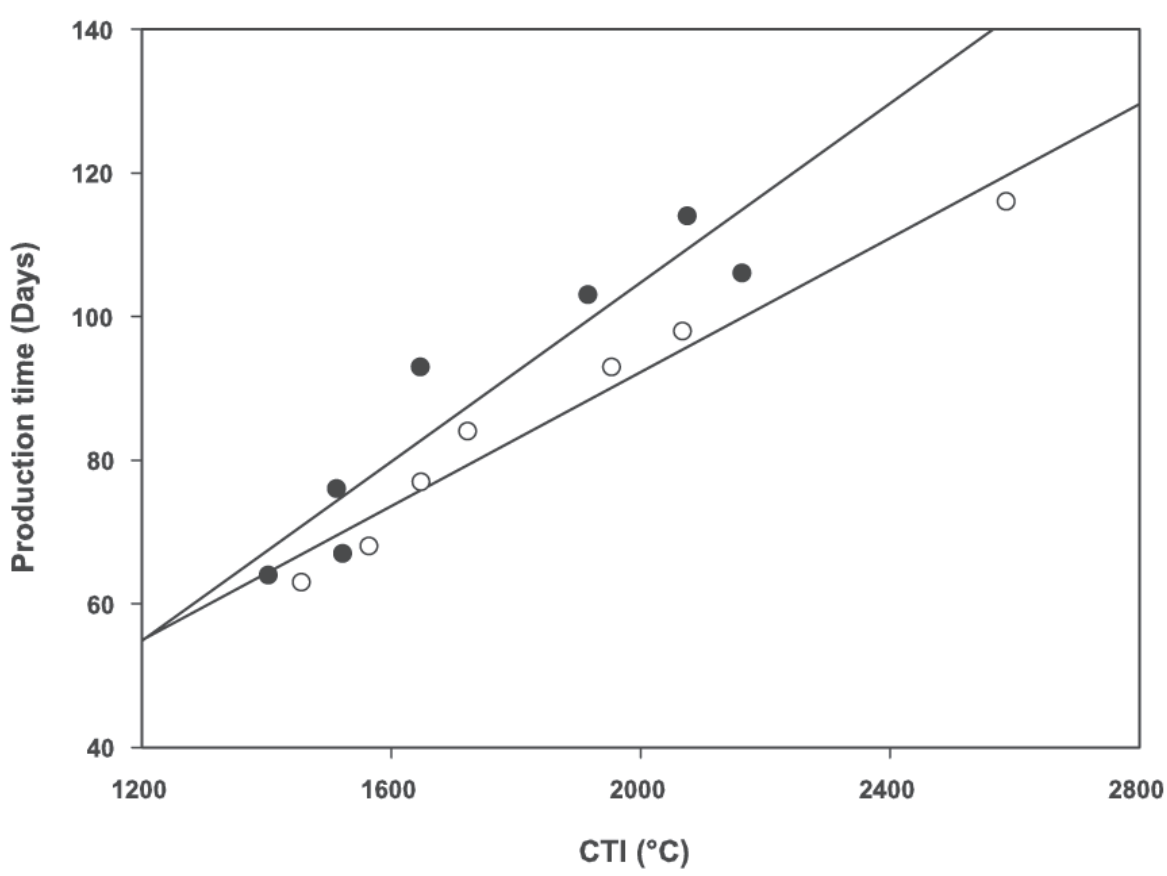

Fig. 1. Production period of Hibiscus rosa-sinensis L. in a dynamic climate (DC) (closed circle, $\left.R^{2}=0.87\right)$ and in a traditional climate (TC) (open circle, $R^{2}=0.96$ ), as influenced by cumulative temperature integral (CTI). Lines represents linear regression and circles are measured values.

in relation to production time and dry weight accumulation. In six of the seven experiments, the dry weight of plants was not significantly different between the two climates (Table 4). Dry weight accumulation is often related to the amount of light that a plant receives during development (Monteith, 1972). If this is the only factor, however, plants in the DC would have had a higher dry weight in all experiments. It has been shown that utilization of the irradiance is affected by temperature (Liu and Heins, 1997). The higher, 24-h average temperature (AT) in the TC might therefore compensate for the lower irradiance level (Table 3) in the TC. In the experiment in which the dry matter production was lower in the DC compared to the TC, the PPF was also low. The combination of very low irradiance and low temperature will retard plant growth to a higher degree than when plants are subjected to the factors individually.

Temperature, $\mathrm{CO}_{2}$ concentration and radiation are important in relation to production time and dry weight accumulation. TI alone does not explain the production time. As growers need to schedule crop production, more research is needed to explain the correlation between climate and production time.

In five of the seven experiments, plants in the DC were shorter than plants in the TC. A positive effect of ADT on plant height has been shown in tomato (Langton and Cockshull, 1997) and chrysanthemum (Karlsson et al., 1989; Carvalho et al., 2002). In the five experiments where plants from the DC were shorter, the ADT was lowest in the DC, which might explain the decreased height in plants. The two experiments in which plant height was identical occurred in periods with a high natural irradiance, where ADT was either equal to or higher in the DC. In all the experiments, the night temperatures were lower in the DC. With a higher night than day temperature (negative DIF), stem elongation growth is limited, while a high positive DIF (higher day than night temperature) enhances elongation growth in a number of species (Cockshull et al., 1995; Erwin et al., 1989; Karlsson et al., 1989; Moe and Heins, 1990). The average positive DIF is higher in a DC compared to a TC, but the plants are shorter (Table 5). A low night temperature is known to decrease the effect of DIF in cucumber (Grimstad and Frimanslund, 1993). The average night tem- perature for the seven experiments was 16.8 ${ }^{\circ} \mathrm{C}$ in the DC and $20.2{ }^{\circ} \mathrm{C}$ in the TC. In some periods, the temperature was as low as $15^{\circ} \mathrm{C}$ in the $\mathrm{DC}$, and this might explain the reduced or absent effect of the positive DIF. Since DIF was calculated based on averages during the day and the whole production period, the large variations during the day and differences between days are masked. The variations might influence the final plant height, but to analyze the effect of the development, plant height has to be measured more frequently. The reduction in plant height would be an advantage to the producer since less chemical growth retardants have to be applied during production.

It has been shown in Hibiscus, that the number of buds increases strongly in high PPF conditions (Ottosen and Mentz, 2000). Plants grown in a DC receive more light in high irradiance periods, since screens are not used for shading. The number of buds and flowers is not higher in the DC. No correlation between buds and flowers and ADT or CTI can be found in either climate. The number of lateral breaks was either the same or more in the plants from the DC.

Growth of a heat-demanding plant in a DC, where temperature is allowed to drop to $15{ }^{\circ} \mathrm{C}$, is possible. To achieve good plant quality and save on energy at the same time, accurate management of a dynamic climate is important. Currently, dynamic regulation based on ideas from the DC is practiced in Danish nurseries, since energy savings of this magnitude cannot be ignored. However, use of a DC needs to be carefully controlled to ensure correct production time and to have plants marketable on specific days.

\section{Literature Cited}

Aaslyng, J.M., N. Ehler, P. Karlsen, and E. Rosenqvist. 1999. A component-based climate control system for decreasing greenhouse consumption. Acta Hort. 507:35-41.

Aaslyng, J.M., J.B. Lund, N. Ehler, and E. Rosenqvist. 2003. IntelliGrow: A greenhouse component-based climate control system. Environ. Model. Software 18:657-666.

Aaslyng, J.M., N. Ehler, and L. Jakobsen. 2005. Climate control software integration with a greenhouse environmental control computer. Environ. Model. Software 20:521-527.

Bailey, B.J. 1988. Control strategies to enhance the performance of greenhouse thermal screens. J. Agr. Eng. Res. 40:187-198.

Bailey, B.J. and I. Seginer. 1989. Optimum control of greenhouse heating. Acta hort. 245:512-518.

Bredenbeck, H. 1989. Energy saving green-

Table 4. Effects of dynamic (DC) and traditional (TC) climates on height (mm), plant dry weight ( $\mathrm{g}$ ), number of buds and flowers and number of lateral breaks. Data on the number of buds and flowers for the last two experiments are unfortunately lost. Values followed by different letters are significantly different $(P$ $\leq 0.05$ ); values with similar letters are not significant. Letters are comparable within each experimental period and plant parameter.

\begin{tabular}{|c|c|c|c|c|c|c|c|c|}
\hline \multirow{2}{*}{$\begin{array}{l}\text { Experimental } \\
\text { period }\end{array}$} & \multicolumn{2}{|c|}{$\begin{array}{c}\mathrm{Ht} \\
(\mathrm{mm})\end{array}$} & \multicolumn{2}{|c|}{$\begin{array}{l}\text { Dry wt } \\
(\mathrm{g})\end{array}$} & \multicolumn{2}{|c|}{$\begin{array}{l}\text { Buds and flowers } \\
\text { (no.) }\end{array}$} & \multicolumn{2}{|c|}{$\begin{array}{c}\text { Lateral breaks } \\
\text { (no.) }\end{array}$} \\
\hline & $\mathrm{DC}$ & $\mathrm{TC}$ & $\mathrm{DC}$ & $\mathrm{TC}$ & $\mathrm{DC}$ & $\mathrm{TC}$ & $\mathrm{DC}$ & TC \\
\hline January 1998-April 1998 & $560.6 \mathrm{a}$ & $523.3 \mathrm{a}$ & $33.4 \mathrm{a}$ & $31.8 \mathrm{a}$ & $47.4 \mathrm{a}$ & $41.4 \mathrm{a}$ & $7.4 \mathrm{a}$ & $6.7 \mathrm{a}$ \\
\hline November 1998-February 1999 & $582.2 \mathrm{~b}$ & $688.3 \mathrm{a}$ & $39.5 \mathrm{a}$ & $42.1 \mathrm{a}$ & $49.7 \mathrm{~b}$ & $62.8 \mathrm{a}$ & $12.3 \mathrm{a}$ & $11.9 \mathrm{a}$ \\
\hline February 1999-May 1999 & $525.6 \mathrm{~b}$ & $636.1 \mathrm{a}$ & $42.0 \mathrm{a}$ & $42.6 \mathrm{a}$ & $34.6 \mathrm{a}$ & $38.0 \mathrm{~b}$ & $16.0 \mathrm{a}$ & $10.8 \mathrm{a}$ \\
\hline January 2000-April 2000 & $453.0 \mathrm{~b}$ & $636.1 \mathrm{a}$ & $21.6 \mathrm{a}$ & $25.1 \mathrm{a}$ & $37.7 \mathrm{a}$ & $18.2 \mathrm{~b}$ & $13.4 \mathrm{a}$ & $9.5 \mathrm{~b}$ \\
\hline April 2000-June 2000 & $567.8 \mathrm{a}$ & $558.3 \mathrm{a}$ & $25.0 \mathrm{a}$ & $25.0 \mathrm{a}$ & $27.4 \mathrm{a}$ & $26.2 \mathrm{a}$ & $16.8 \mathrm{a}$ & $12.9 \mathrm{~b}$ \\
\hline January 2002-April 2002 & $468.1 \mathrm{~b}$ & $695.0 \mathrm{a}$ & $19.7 \mathrm{~b}$ & $26.9 \mathrm{a}$ & --- & --- & $10.1 \mathrm{a}$ & $7.3 \mathrm{~b}$ \\
\hline April 2002-June 2002 & $384.4 \mathrm{~b}$ & $528.8 \mathrm{a}$ & $24.5 \mathrm{a}$ & $21.1 \mathrm{a}$ & --- & --- & $13.0 \mathrm{a}$ & $10.5 \mathrm{~b}$ \\
\hline
\end{tabular}


house system with solar energy. Acta Hort. 245:300-303.

Carvalho, S.M.P., E. Heuvelink, R. Cascais, and O. van Kooten. 2002. Effect of a day and night temperature on internode and stem length in Chrysanthemum: Is everything explained by DIF? Ann. Bot. 90:111-118.

Cockshull, K.E., D.W. Hand, andF.A. Langton.1981. The effects of day and night temperature on flower initiation and development in chrysanthemum. Acta Hort. 125:101-110.

Cockshull, K.E. 1994. Possible energy saving techniques for mild winter climates. Acta Hort. 366:133-140.

Cockshull, K.E., F.A. Langton, and C.R.J Cave. 1995. Differential effects of different DIF treatments on Chrysanthemum and Poinsettia. Acta Hort. 378:15-25.

Ehler, N. and P. Karlsen. 1993. OPTICO_A model based real-time expert system for dynamic optimization of $\mathrm{CO}_{2}$ enrichment of greenhouse vegetable crops. J. Hort. Sci. 68 (4):485-494.

Erwin, J.E., R.D. Heins, and M.G. Karlsson. 1989. Thermomorphogenesis in Lilium longiflorum. Amer. J. Bot. 76:47-52.

Grimstad, S.O. and E. Frimanslund. 1993. Effect of different day and night temperature regimes on greenhouse cucumber young plant production, flower bud formation and early yield. Scientia Hort. 53:191-204.

Hansen, J.M., N. Ehler, P. Karlsen, K. Høgh-Schmidt, and E. Rosenqvist. 1996a. Acomputer controlled chamber system designed for greenhouse microclimate modelling and control. Acta Hort. 440:310-315.

Hansen, J.M., N. Ehler, P. Karlsen, K. Høgh-Schmidt and E. Rosenqvist. 1996b. Decreasing the environmental load by a photosynthetic based system for greenhouse climate control. Acta Hort. 440:105-110.

Karlsson M.G., R.D. Heins, J.E. Erwin, R.D. Berghage, W.H. Carlson, and J.A. Biernbaum. 1989. Temperature and photosynthetic photon flux influence Chrysanthemum shoot development and flower initiation under short-day conditions. J. Amer. Soc. Hort. Sci. 114:158-163.

Körner, O. and H. Challa. 2004. Temperature integration and process-based humidity control in chrysanthemum. Computers Electronics Agr. 43:1-21.

Langton, F.A. and K.E. Cockshull. 1997. Is stem extension determined by DIF or by absolute day and night temperatures? Scientia Hort. 69:229-237.

Liu, B. and R.D. Heins. 1997. Is plant quality related to the ratio of radiant energy to thermal energy? Acta Hort. 435:171-182.

Meyer, J. 1981. Energy saving with mobile screens. Acta Hort. 115:677-684.

Moe, R. and R. Heins. 1990. Control of plant morphogenesis and flowering by light quality and temperature. Acta Hort. 272:81-89.
Monteith, J.L. 1972. Solar radiation and productivity in tropical ecosystems. J. Appl. Ecol. 9:747-766.

Nederhoff, E.M. 1988. Dynamic optimization of the $\mathrm{CO}_{2}$ concentration in greenhouses: An experiment with cucumber (Cucumic sativus L.) Acta Hort. 229:341-349.

Ottosen, C.-O. and J. Mentz. 2000. Biomass accumulation and photosynthesis of ornamentals in elevated $\mathrm{CO}_{2}$ conditions. Gartenbauwiss. 65:35-39.

Ottosen, C.-O., E. Rosenquist, J. M. Aaslyng, and L. Jakobsen. 2004. Dynamic climate control or average temperature control? Acta Hort. (in press).

Rijsdijk, A. A. 2000. Temperature integration on a 24-hour base: A more efficient climate control strategy. Acta Hort. 519:163-169.

Santamouris, M., C.A. Balaras, E. Dascalaki, and M. Vallindras. 1994. Passive solar agricultural greenhouses: A worldwide classification and evaluation of technologies and systems used for heating purposes. Solar Energy 53(5):411-426.

SAS Institute, 1985. SAS/STAT Guide for personal computers. version 6. SAS Inst. Inc., Cary, N.C.

Skov, O., Kronmann J. and Marienlund, L. 1993. Brancheenergianalyse 1993 for gartnerierhvervet (in Danish). Danish Growers' Assn., Odense SV, Danmark. 